\title{
AGRICULTURAL TRICHOTHECENE MYCOTOXIN CONTAMINATION AFFECTS THE LIFE-HISTORY AND REDUCED GLUTATHIONE CONTENT OF FOLSOMIA CANDIDA WILLEM (COLLEMBOLA)
}

\author{
Borbála Szabó ${ }^{1,2 *}$, Benjamin Bálint ${ }^{1}$, Miklós Mézes ${ }^{3,4 * *}$, Krisztián Balogh ${ }^{3,4}$ \\ ${ }^{1}$ Szent István University, Department of Zoology and Animal Ecology \\ H-2100 Gödöllö, Páter K. u. 1, Hungary; https://orcid.org/0000-0002-1289-2320 \\ ${ }^{2}$ Centre for Ecological Research, Danube Research Institute \\ H-1113 Budapest, Karolina u. 29, Hungary \\ *E-mail: szabo.borbala@okologia.mta.hu; https://orcid.org/0000-0001-7587-1597 \\ ${ }^{3}$ Szent István University, Department of Nutrition, H-2100 Gödöllö, Páter Károly u. 1, Hungary; \\ https://orcid.org/0000-0002-9435-4568; **https://orcid.org/0000-0003-2323-833X \\ ${ }^{4}$ MTA-KE-SZIE Mycotoxins in the Food Chain Research Group \\ H-6400 Kaposvár, Guba Sándor u. 40, Hungary
}

There is limited data available concerning the effect of T-2/HT-2 toxin or deoxynivalenol (DON) on invertebrates such as springtails, and no data on their life history and oxidative stress. Control maize and DON or T-2 toxin contaminated maize were fed to Folsomia candida with a toxin content of $16324 \mathrm{mg} \mathrm{DON} \mathrm{kg}^{-1}$ or $671 \mathrm{mg} \mathrm{T}^{\mathrm{T}}-2 \mathrm{~kg}^{-1} \mathrm{maize}$. Ten to twelve days old animals were investigated in a life-history test and a stress protein test.

T-2 toxin did not affect Folsomia candida in any measured parameters. The DON exposed group showed decreased growth and reproduction, and a higher survival rate. DON treatment resulted in lower protein content, while reduced glutathione content was higher than in control. It suggests that DON activated the glutathione-related detoxification pathway, which possibly causes a higher survival rate. The results also suggest that the oral toxicity of DON or T-2 is lower than through physical contact.

For that reason, DON and T-2 toxin contaminated maize is not suggested to be used as green manure in the native state. Alternative solutions could be using mycotoxin contaminated maize for biogas production, or after decontamination by bacterial strains, it can be used as organic fertilizer.

Key words: Folsomia, Collembola, trichothecene, life-history, mycotoxin, glutathione.

\section{INTRODUCTION}

Fusarium genera include mycotoxin producing fungi, and they produce trichothecenes, such as T-2 toxin and its metabolite HT-2 toxin, or deoxynivalenol (DON), which frequently occur in cereals as a result of Fusarium infection (Bottalico \& Perrone 2002, Logrieco et al. 2002). DON and T-2/HT-2 toxin can get into the soil with infected kernels, plant residues (ELMHOLt 2008), and in dry years, inoculum can disperse into the soil during harvest (HorN 2003). Therefore, it is relevant to take the effects of DON and T-2/HT-2 toxin on soil fauna and flora into account. However, trichothecenes are degraded by soil 
microorganisms (Ji et al. 2016), the efficiency of degradation is not known, and the effect of trichothecene mycotoxins on the fungal and bacterial ecosystems of the soil is not entirely well known either (ABID et al. 2011). There is little data available about the effect of mycotoxins on Collembola genera, despite their preference of Fusarium sp. in their diet (Goncharov et al. 2020). In our previous study, our goal was to reveal whether the survival, the reproduction, or the grazing behaviour of Folsomia candida Willem is vulnerable to T-2 toxin or DON (SzABó et al. 2019) and found that both mycotoxins reduced the juvenile number in low concentrations and inhibited feeding behaviour for a time.

Folsomia candida is a model organism extensively used in soil ecotoxicology (Fountain \& Hopkin 2005, Krogh 2009, Szabó et al. 2018). It is a cosmopolitan species, distributed in organic material rich soils (FounTAIN \& HopKIN 2005, KROGH 2009), and has a role in the humification of organic matter and the regulation of the soil microbial community (Hopkin 1997). Collembolans can graze mycotoxigenic moulds (LARSEn et al. 2008, InNOCENTI \& SABATINI 2018) and mycotoxins, as antifungivore metabolites (Vega \& Mercadier 1998, Rohlfs et al. 2007, DöLl et al. 2013).

Trichothecene mycotoxins, such as T-2/HT-2 toxin or DON, induce oxidative stress in animals due to the epoxy group on their trichothecene ring (Wu et al. 2017). However, previously a transcriptional response, including expression of genes encoding antioxidant enzymes, was found only as a response to Aspergillus mycotoxin (sterigmatocystin) in F. candida (JANssens et al. 2010), which is known to induce oxidative stress in vertebrates (Kövesi et al. 2019). Other environmental oxidative stressors, such as heavy metals, are also known to induce oxidative stress in F. candida (MARIA et al. 2014).

The life-history parameters of $F$. candida are flexible and rapidly adaptable to changes; for example, in the case of crowding and scarce food, the animals can adjust the number and the size of the eggs in the next clutch (TulLy \& FERRIÈRE 2008). In the xenobiotic polluted environment, springtails can adjust their reproduction, e.g., Paronychiurus kimi (Lee) treated with paraquat, can compensate its decreasing fertility with an earlier maturation ( $\mathrm{CHO}_{\mathrm{er}}$ et al. 2008). Also, feeding F. candida with zinc-polluted food resulted in decreased growth, later maturation, and decreased egg numbers (SмIT et al. 2004). In the long-term mild life-history changes can add up, e.g., F. candida fed with leaves of Bt-maize produced larger eggs and showed a higher growth rate (SzABó et al. 2017). Isothiocyanate, a secondary metabolite of some plants, reduces the reproduction of $F$. candida while stimulates the transcription of stress-related genes, such as glutathione-S-transferase (vAN OMMEN KLOEKE et al. 2012).

Trichothecenes induce free radical formation, and consequently, lipid peroxidation and decrease the level of antioxidant enzymes (Wu et al. 2017). Glutathione is a tripeptide, and its basic function is to protect the organism 
against reactive oxygen and nitrogen species (Lushснак 2012). The reduced (GSH) and oxidized (GSSG) form of glutathione are maintaining the redox state of the cells (SIEs 1999). Moreover, it is proved that DON can form adducts with GSH; therefore, it has a role in the detoxification of DON (GARDINER et al. 2010). Glutathione peroxidase (GPx) is an antioxidant enzyme protecting the organism from the effects of free radicals generated by toxins, pollutants, or infections (Wu et al. 2017). T-2 toxin can decrease the GPx level of porcine ovarian cells (CAPCARova et al. 2015), and DON could decrease GPx levels in in vitro cell cultures (Costa et al. 2009). Malondialdehyde (MDA) is a metastable end product of lipid peroxidation (Traverso et al. 2004), and its level is elevated by DON exposure (Wu et al. 2017). Nevertheless, Bodea et al. (2009) found that DON decreased the MDA levels of the HepG2 cell line.

The purpose of the present study was to reveal the potential effects of T-2/HT-2 toxin or DON on growth, reproduction parameters, and several oxidative stress parameters in F. candida. The toxin concentrations of the experimentally contaminated maize were $16324 \mathrm{mg} \mathrm{DON} \mathrm{kg}^{-1}$ dry matter or $671 \mathrm{mg}$ T-2 toxin and its active metabolite $0.002 \mathrm{mg}$ HT-2 toxin $\mathrm{kg}^{-1}$ dry matter. In Europe, natural contamination of corn in 2019 was $0.36-8.60 \mathrm{mg}^{\mathrm{DON} \mathrm{kg}}{ }^{-1}$ and $0.02-4.13 \mathrm{mg} \mathrm{T}-2 \mathrm{~kg}^{-1}$ toxin (BIOMIN® Мrcotoxin Survey 2020). Our concentrations are higher than the naturally occurring contamination level, but the purpose of this study was to investigate the potentially toxic effects of the trichothecene mycotoxins mentioned above. According to our best knowledge, this is the first study about the effects of DON or T-2/HT-2 toxin on lifehistory parameters and oxidative stress parameters of $F$. candida.

\section{MATERIAL AND METHODS}

Folsomia candida Willem, 1902 (Collembola, Isotomidae) used in this study was obtained from the stock population reared in the laboratory of the Szent István University, Department of Zoology and Animal Ecology during the past 20 years. Collembolans were kept in Petri-dishes with a diameter of $9 \mathrm{~cm}$ based on the method of Gото (1960). The plaster of Paris mixed with activated charcoal (10:1 volume ratio) was poured into the Petri dish. The animals were kept at a temperature of $20 \pm 0.2^{\circ} \mathrm{C}$, with $\sim 100 \%$ humidity and in total darkness. Petri dishes were watered regularly to maintain the humidity at a constant level. During this operation, they were aerated. All phases of the experiment were performed under the above-mentioned environmental conditions.

The animals (5 per Petri dish) were fed ad libitum either grounded control maize kernel or maize kernel experimentally contaminated with DON or T-2/HT-2 toxin. Fresh food was provided every week. The mycotoxin concentrations of the experimentally contaminated maize were $16324 \mathrm{mg}$ DON kg$^{-1}$ dry matter or $671 \mathrm{mg} \mathrm{T-2}$ and $0.002 \mathrm{mg}$ HT-2 toxin $\mathrm{kg}^{-1}$ dry matter. These concentrations are higher than the currently naturally occurring concentrations, however, it is not possible to make concentration series for F. candida, while the animals could sort out the toxin contaminated and non-contaminated maize grains in 
case of a mixture. Therefore, we follow the example of previous researches who worked with mycotoxin producing fungus where only one concentration and non-contaminated food was offered (Rohlfs et al. 2007, JANSSENs et al. 2010, StAADEN et al. 2010, STÖTEFeld et al. 2012). The inoculation of maize, as the most effective substrate for mycotoxin production, with the DON producing strain of Fusarium graminearum (NRRL 5883) or with T-2 toxin-producing strain of Fusarium sporotrichioides (NRRL 3299) was made according to SzABó-Fodor et al. (2015). DON content of the inoculated corn was determined according to Pussemier et al. (2006), and T-2 and HT-2 toxin concentration was assayed by the method of TREBSTEIN et al. (2008) using isocratic HPLC with fluorescence detector after immunoaffinity clean-up. The quality of the toxin contaminated food is usually different than the non-contaminated, which could cause differences in the measured parameters of $F$. candida (BAKONYI et al. 2011). The nitrogen content of the Fusarium infected maize samples was high $(3.22 \%$ in case of DON contaminated and $2.56 \%$ in case of T-2 toxin contaminated maize, respectively), due to mould infection; therefore, we choose a control with the highest nitrogen content from the available samples, Mv251-60 (1.72\%). Ten-twelve day old, synchronised animals were used in the experiments. There were two series of experiments. The first series contained five animals in each replicate (5 replicate per treatment group) to measure the life-history parameters (initial length, final length, relative growth, number of eggs, egg volume, unhatching rate, and total reproduction investment, survival). The second series contained fifty animals in each replicate (5 replicates per treatment group), where the reduced glutathione (GSH) concentration, glutathione-peroxidase (GPx) activity, protein and malondialdehyde (MDA) content was determined.

In the third week of mycotoxin exposure, the animals in the first series were transferred to a fresh Petri dish, which induces egg-laying in most cases. On the seventh day after transporting, when the eggs were 5-7 days old, the clutches of eggs were spread carefully to count them with a very soft wet brush to avoid damage by spreading, and a digital photo was taken of each clutch. The spread clutches were photographed by ISH 130 camera (Tucsen Photonics, Fujian) and 0.5× objective on an Olympus SZ60 stereomicroscope (Olympus, Tokyo) to count egg number and measure the size of the eggs. Every egg got a unique number, where random numbers were generated for every egg per replicate. Ten randomly chosen eggs were measured from every Petri-dish. The measurements were carried out by Image J software (SCHNEIDER et al. 2012). The shortest and longest diameters of the eggs were measured. The volume of the eggs was calculated according to the prolate spheroid equation $\left(V=4 / 3 \pi \times a \times b^{2}\right.$, where " $a$ " is the longer half diameter, and " $\mathrm{b}$ " is the shorter half diameter (SATTERLy 1960)). In the statistical models, the cubic root of the volume was used to reach normal distribution. The total reproduction investment was calculated (total number of eggs multiplied with mean egg volume).

Ten days after laying the eggs, a repeated photo was taken from the spread clutches to check the unhatching ratio (number of unhatched eggs/numbers of laid eggs).

The body length of five animals from each replicate was measured at the start (initial length, I) and the end (final length, F) of the experiment from the front of the head to the end of the last abdomen segment by digital photography. The mean of the five animals was used for the statistical analysis. The experiment lasted for 28 days; therefore, the animals were 39-41 days old at the end. The relative growth $(\mathrm{R})$ of the animals was calculated as $\mathrm{R}=(\mathrm{F}-\mathrm{I}) / \mathrm{I}$.

At the same time, 28 days after the start of the mycotoxin exposure, animals of the second series (50 animals per Petri dish) were collected into micro centrifuge-tubes, and served as a pooled sample ( 5 replicates from each treatment group) and stored at $-70^{\circ} \mathrm{C}$ until analysis.

Glutathione redox and lipid peroxidation parameters were measured in pooled samples of fifty animals, which were homogenised in $500 \mu \mathrm{l}$ saline solution $(0.65 \mathrm{w} / \mathrm{v} \% \mathrm{NaCl})$. 
The concentration of GSH was determined, according to RAHMAN et al. (2007). GPx activity was measured as described by MAткоvics et al. (1988), where the loss of GSH was measured using 5,5'-dithiobis-2-nitrobenzoic acid (DTNB). The terminal phase marker of lipid peroxidation was determined by measuring the MDA concentration according to the 2-thiobarbituric acid method of PLACER et al. (1966) using 1,1,3,3-tetraethoxypropane as standard.

MDA concentrations were measured in the native homogenates of collembolans, while GSH concentration and GPx activity were determined in the supernatant fraction after centrifugation $\left(10,000 \mathrm{~g}\right.$ for $10 \mathrm{~min}$ at $\left.4{ }^{\circ} \mathrm{C}\right)$ of the homogenates. The two latter parameters were calculated to the protein content of the $10,000 \mathrm{~g}$ supernatant, measured by Folin-Ciocalteu reagent according to the method of Lowry et al. (1951).

The statistical analyses were made using the R Statistical program 3.6.3 (R CoRE TEAM 2020). The data were analysed with a simple linear model except for the egg volume, which was analysed with a mixed effect model from the nlme package (PINHEIRo et al. 2013) with the Petri-dish ID as the random subject. The measurements on the eggs from the same clutch were not independent, which is why the model corrects the calculation accordingly.

All of the data sets of the experiment met the requirements of normality according to the diagnostic plots (Residual variances, QQ plot, and Cook distance plot). The homogeneity of variance was tested with Levene's test, and paired difference from the control was checked with F-test. All of the data sets of the experiment met the requirements of normality according to the diagnostic plots (Residual variances, QQ plot, and Cook distance plot).

\section{RESULTS}

The T-2/HT-2 toxin exposed group did not differ in any measured parameters from the control (Tables 1-2).

Table 1. Mean and standard deviation of the parameters of Folsomia candida at the control and the two treated group: DON or T-2/HT-2 contaminated maize fed. All values are mean \pm st.dev.

\begin{tabular}{lccc}
\hline & Control & DON & T-2 \\
\hline Survival (number) & $2.8 \pm 0.84$ & $4.4 \pm 0.55$ & $3.20 \pm 1.92$ \\
Initial length $(\mathrm{mm})$ & $0.71 \pm 0.04$ & $0.68 \pm 0.03$ & $0.76 \pm 0.06$ \\
Final length $(\mathrm{mm})$ & $1.88 \pm 0.14$ & $1.70 \pm 0.11$ & $2.10 \pm 0.22$ \\
Relative growth & $1.64 \pm 0.08$ & $1.50 \pm 0.06$ & $1.68 \pm 0.18$ \\
Total number of eggs & $89.00 \pm 55.57$ & $44.80 \pm 27.22$ & $192.60 \pm 198.12$ \\
Unhatching ratio & $0.29 \pm 0.35$ & $0.35 \pm 0.39$ & $0.19 \pm 0.15$ \\
Egg volume $\left(\mathrm{mm}^{3}\right)$ & $0.0009 \pm 0.0005$ & $0.0011 \pm 0.0004$ & $0.0009 \pm 0.0004$ \\
Total reproduction & $0.1856 \pm 0.1219$ & $0.0618 \pm 0.0162$ & $0.2107 \pm 0.1581$ \\
Total protein content $(\mathrm{g} / \mathrm{L})$ & $16.19 \pm 3.12$ & $11.64 \pm 1.84$ & $21.18 \pm 11.39$ \\
GSH $(\mu \mathrm{mol} / \mathrm{g}$ protein) & $17.97 \pm 4.60$ & $24.80 \pm 1.69$ & $15.76 \pm 7.31$ \\
GPx $(\mathrm{U} / \mathrm{g}$ protein) & $6.03 \pm 2.09$ & $8.58 \pm 2.57$ & $7.88 \pm 6.25$ \\
MDA $(\mu \mathrm{mol} / \mathrm{ml})$ & $5.78 \pm 0.94$ & $4.24 \pm 1.20$ & $7.04 \pm 4.37$ \\
\hline
\end{tabular}


Table 2. The statistical differences in mean from the control in case of different mycotoxin contaminated feeding of Folsomia candida. The significant values are bolded. The negativity or positivity of the t-value gives the direction of the effect. GSH: reduced glutathione; GPx: glutathione peroxidase; MDA: malondialdehyde.

\begin{tabular}{lcccc}
\hline & \multicolumn{2}{c}{ DON } & \multicolumn{2}{c}{ T-2 } \\
\cline { 2 - 5 } & t-value & p-value & t-value & p-value \\
\hline Survival (number) & 3.6 & 0.007 & 0.4 & 0.681 \\
Initial length $(\mathrm{mm})$ & -1.3 & 0.228 & 1.6 & 0.133 \\
Final length $(\mathrm{mm})$ & -2.3 & 0.054 & 1.9 & 0.101 \\
Relative growth & -3.2 & 0.013 & 0.4 & 0.691 \\
Total number of eggs & -1.6 & 0.149 & 1.1 & 0.293 \\
Unhatching ratio & 0.2 & 0.811 & -0.5 & 0.621 \\
Egg volume (mm $\left.{ }^{3}\right)$ & 1.0 & 0.365 & 0.1 & 0.959 \\
Total reproduction & -2.0 & 0.087 & 0.3 & 0.795 \\
Total protein content $(\mathrm{g} / \mathrm{L})$ & -2.8 & 0.023 & 0.9 & 0.372 \\
GSH ( $\mu$ mol/g protein) & 3.1 & 0.014 & -0.6 & 0.583 \\
GPx $(\mathrm{U} / \mathrm{g}$ protein) & 1.7 & 0.124 & 0.6 & 0.548 \\
MDA $(\mu \mathrm{mol} / \mathrm{ml})$ & -2.3 & 0.054 & 0.6 & 0.547 \\
\hline
\end{tabular}
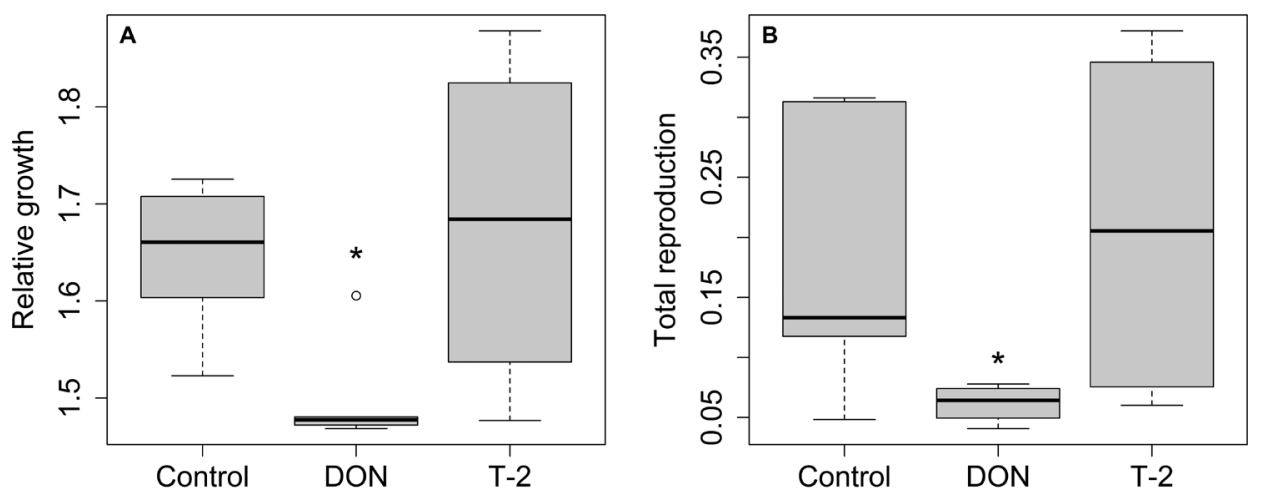

Fig. 1. A relative growth of Folsomia candida on the relation of the contaminated food; significant difference in mean B. Total reproduction of Folsomia candida in the contaminated food, significant difference in variance. ${ }^{*}: \mathrm{p}<0.05$. The band inside the box is the median. The bottom and the top of the box are the first and third quartiles. The ends of the whiskers are the minimum and maximum, excluding outliers. Open circle: outlier (more than $3 / 2$ times of the upper or lower quartile) 


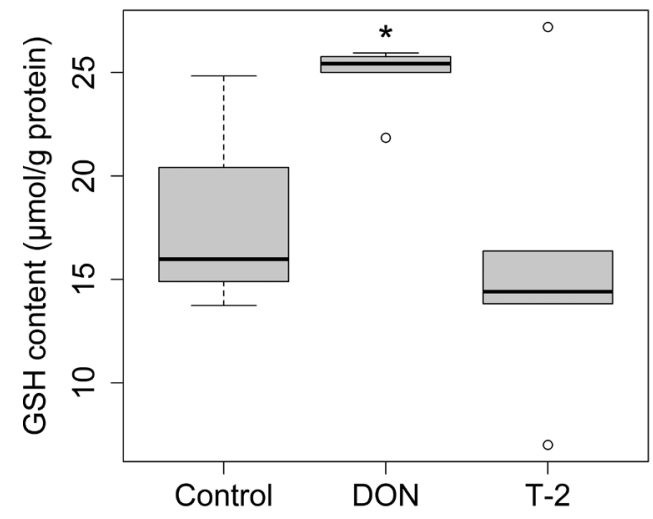

Fig. 2. Reduced glutathione (GSH) content of Folsomia candida in the relation of the contaminated food. Significant difference in mean: ${ }^{*}: p$ $<0.05$. The band inside the box is the median. The bottom and the top of the box are the first and third quartiles. The ends of the whiskers are the minimum and maximum, excluding outliers. Open circle: outlier (more than $3 / 2$ times of the upper or lower quartile)
The DON exposed group had a smaller growth at the end of the experiment (Fig. 1A), but the survival was higher, and the reproduction was strictly regulated (the variance was low) (Fig. 1B). DON exposure caused lower variance in the total reproduction than in control $(\mathrm{F}=56.6 ; \mathrm{p}=0.007)$ (Fig. 1B). Reduced glutathione content was significantly higher in the DON exposure group than in the control group (Fig. 2).

Among the biochemical parameters, the malondialdehyde content and GPx activity did not change due to the mycotoxin exposure (Tables 1 and 2). The protein content of the F. candida homogenate was lower as a result of the DON exposure, while T-2 toxin did not have such effect (Tables 1 and 2).

\section{DISCUSSION}

T-2/HT-2 toxin was not toxic to the animals through oral exposure, but DON toxin decreased the growth of the animals and activated the GSH detoxification system, also reduced the variance of reproduction.

We found no effect in the T-2/HT-2 group, which shows that T-2/HT-2 toxin contaminated food at the current dose used in the present study is not toxic to F. candida. Oxidative stress caused by DON decreases activities of the antioxidant enzymes at the early phase of the exposure (Wu et al. 2017). Still, in long-term exposure, the antioxidant enzyme levels are increasing (BodeA et al. 2009), possibly due to the activation of the antioxidant gene cluster (TAGUCHI et al. 2011). The regulation of the antioxidant response in Collembolans is not known. Nevertheless, it is more than possible that this regulatory mechanism is conservative in all aerobic organisms, which is supported by the presence of regulatory genes, and also their orthologues are present even in prokaryotes (Lushснак 2011). In the present study, elevated GSH content was found in the DON exposed group, which would be a sign of oxidative stress response. This result was supported by the previous findings of the primary effect of 
GSH on oxidative stress response (Lushснак 2012). However, this stimulated detoxification system also increased the survival of the DON exposed group compared to the control. The other parameters of oxidative stress, such as MDA content and GPx activity, did not change, which suggested that GSH synthesis and/or reduction of glutathione disulphide would be the first step of response at the dose applied, and it was adequate for inhibition of oxygen free radical formation and further lipid peroxidation. In accordance with this result, aflatoxin B1 also induced the GSH detoxification system in hepatopancreas and intestine of Litopenaeus vannamei Boone (Penaeidae) (WANG et al. 2019). DON and T-2/HT-2 toxin both inhibit protein synthesis and cause cell death (Speijers \& Speijers 2004), which could be the universal mechanism behind impairing the hatchability of eggs such in springtails and avian species (Diaz et al. 1994). However, the hatching rate was not affected in Collembolans either by DON or T-2 toxin exposure at the dose applied. There was also no difference in the reproduction parameters, possibly due to the low repeat number, but the variance of the DON group was much lower than the control in the case of the total reproduction. This result suggests that natural selection at the DON group is stronger; therefore, the group is more strictly regulated. This result is similar to the findings of SMIT et al. (2004) when excess dietary zinc reduced growth and the number of eggs in F. candida.

Smaller growth and more regulated reproduction could be a trade-off with detoxification and survival. This trade-off agrees with other studies, where they found that in case of stress, F. candida rather invest energy into survival than into reproduction (CROMmentuijn et al. 1997, Fox et al. 1997, Mousseau \& Fox 1998, Congdon et al. 2001, Tully \& Ferrière 2008). If F. candida was treated with an isothiocyanate, a secondary plant metabolite, the reproduction decreased, while the stress-related genes were upregulated (van Ommen Kloeke et al. 2012). The resource allocation from reproduction to detoxification is observable in the case of Daphnia magna Strauss when it is exposed to zinc, and the detoxification genes are upregulated while the reproduction decreases (VANDEgenUChTE et al. 2010). Compared with the results of our previous study where not the feed but the soil was contaminated, the effect of both mycotoxins was much more pronounced (SzABó et al. 2019). The difference between the two different routes of the application suggests that both mycotoxins probably have higher contact toxicity, which was avoided in the present setup. This result is similar to heavy metal exposure, where those were also more toxic in a contact exposure (Fountain \& Hopkin 2001).

Moreover, not only the decreased total reproduction but the mortality of juveniles could bias the final juvenile number. In our previous study, we found low juvenile numbers in case of lower mycotoxin concentrations (SzABó et al. 2019). However, in our previous study, we used contact exposure in soil, 
with uncontaminated yeast as food, and in the present study, we used oral exposure. This means that the oral toxicity of DON and T-2 is much lower than the contact one, similarly to the heavy metal contamination.

The difference between the effects of DON and T-2 toxin is also based on their chemical structure and water solubility. DON contains three free hydroxyl groups associated with its toxicity (NAGY et al. 2005), and it is soluble in water. The toxicity of T-2/HT-2 toxin is based on its 12,13 epoxy group, and it is less soluble in water (Lr et al. 2011). In the present study, the results also revealed that $F$. candida reduced investment into reproduction while the variance was much lower around a lower mean value. Wolfarth et al. (2013) also found that DON exposure caused low juvenile numbers, which was confirmed in our previous study, too (Szabó et al. 2019). The scenarios of the above-cited reference were similar to our experiments, and the DON exposure caused a decrease in reproduction, without measurable changes in the survival.

Bacterial strains could decrease DON and T-2 contamination (WANG et al. 2019, Zhai et al. 2019, WANg et al. 2020). Devosia insulae A16 can decrease $88 \%$ of DON in 2 days (WANG et al. 2019), while C20 bacterial consortium can degrade almost $70 \mathrm{mg} \mathrm{L}^{-1} \mathrm{DON}$ in 5 days and degrade 15-acetyl-DON, 3-acetyl-DON, and T-2 toxin too (WANG et al. 2020). However, the degradation of toxins before the agricultural application is too expensive to be used in the every-day practice right now.

In conclusion, the results of the present study suggested that the oral route of toxicity of DON or T-2 toxin is lower than the contact route in $F$. candida. The results also revealed that DON activated the glutathione-related detoxification pathway more than T-2/HT-2 toxin, without measurable changes in glutathione peroxidase activity and lipid peroxidation. For that reason, DON and T-2/HT-2 contaminated maize is not suggested to be used as green manure in the native state in the cultivation area due to their adverse effect on Collembola. However, alternative solutions could be using mycotoxin contaminated maize as biogas production or after decontamination by bacterial strains; it could be used as organic fertilizer.

The Authors declare no conflict of interest.

Acknowledgement - The research was supported by the grant NVKP_16-1-2016-0016 of the Hungarian National Research, Development and Innovation Office. Many thanks to Dr. Erika Zándoki and David Ospina from Cornell University, NY, for English grammar corrections. 


\section{REFERENCES}

Abid, M., Leplat, J., Fayolle, L., Gautheron, E., Heraud, C., Gautheron, N., Edel-Hermann, V., Cordier, C. \& Steinberg, C. (2011): Ecological role of mycotoxins in wheat crop residues: consequences on the multitrophic interactions and the development of Fusarium gramineum. Pp. 1-5. In: Landa, B. B., Navas-Cortés, J. A., MontesBorreg, O. M., \& Steinberg, C. (eds): Multitrophic interactions in soil. IOBIC Bulletin 71. Proc. Working Group, Córdoba.

Bakonyi, G., Dolezsai, A., Mátrai, N. \& SzÉKÁcs, A. (2011): Effects of consumption of Btmaize (MON 810) on the Collembolan Folsomia candida, over multiple generations: a laboratory study. - Insects 2(2): 243-252. https://doi.org/10.3390/insects2020243

BIOMIN® Mycotoxin Survey (2020): World mycotoxin survey 2019. 11 pp. https://www. biomin.net/

Bodea, G. O. D., Munteanu, M. C., Dinu, D., Serban, A. I., Roming, F. I., Costache, M. \& Dinischiotu, A. (2009): Influence of deoxynivalenol on the oxidative status of HepG2 cells. - Romanian Biotechnological Letters 14(2): 4349-4359.

Bottalico, A. \& Perrone, G. (2002): Toxigenic Fusarium species and mycotoxins associated with head blight in small-grain cereals in Europe. - European Journal of Plant Pathology 108(7): 611-624. https://doi.org/10.1023/A:1020635214971

Capcarova, M., Petruska, P., Zbynovska, K., Kolesarova, A. \& Sirotkin, A. V. (2015): Changes in antioxidant status of porcine ovarian granulosa cells after quercetin and T-2 toxin treatment. - Journal of Environmental Science and Health - Part B Pesticides, Food Contaminants, and Agricultural Wastes 50(3): 201-206. https://doi.org/10.1080/03 601234.2015.982425

Choi, W. Il., Neher, D. A. \& Ryoo, M. Il. (2008): Life-history trade-offs of Paronychiurus kimi (Lee) (Collembola: Onychiuridae) populations exposed to paraquat. - Ecotoxicology and Environmental Safety 69: 227-232. https://doi.org/10.1016/j.ecoenv.2007.01.008

Congdon, J. D., Dunham, A. E., Hopkins, W. A., Rowe, C. L. \& Hinton, T. G. (2001): Resource allocation-based life histories: a conceptual basis for studies of ecological toxicology. - Environmental Toxicology and Chemistry 20(8): 1698-1703. https://doi.org/ https://doi.org/10.1002/etc.5620200811

Costa, S., Schwaiger, S., Cervellati, R., Stuppner, H., Speroni, E. \& Guerra, M. C. (2009): In vitro evaluation of the chemoprotective action mechanisms of leontopodic acid against aflatoxin B1 and deoxynivalenol-induced cell damage. - Journal of Applied Toxicology 29(1): 7-14. https://doi.org/10.1002/jat.1372

Crommentuijn, T., Doodeman, C. J. A. M., Doornekamp, A. \& Gestel, C. A. M. (1997): Life-table study with the springtail Folsomia candida (Willem) exposed to cadmium, chlorpyrifos and triphenyltin hydroxide. Pp. 275-291. - In: Ecological risk assessment of contaminants in soil. Springer, US. https://doi.org/10.1007/978-1-4615-6361-7_13

Diaz, G. J., Julian, R. J., Seuires, E. J. \& Boermans, H. J. (1994): Individual and combined effects of T-2 toxin and DAS in laying hens. - British Poultry Science 35(3): 393-405. https://doi.org/10.1080/00071669408417704

Döll, K., Chatterjee, S., Scheu, S., Karlovsky, P. \& Rohlfs, M. (2013): Fungal metabolic plasticity and sexual development mediate induced resistance to arthropod fungivory. - Proceedings of the Royal Society B: Biological Sciences 280(1771): 20131219. https:// doi.org/10.1098/rspb.2013.1219

Elmholt, S. (2008): Mycotoxins in the soil environment. In: Karlovsky, P. (ed.): Secondary metabolites in soil ecology. - Soil Biology. Springer-Verlag, Berlin Heidelberg. https:// doi.org/10.1007/978-3-540-74543-3_9 
Fountain, M. T. \& Hopkin, S. P. (2001): Continuous monitoring of Folsomia candida (Insecta: Collembola) in a metal exposure test. - Ecotoxicology and environmental safety 48(3): 275-286. https://doi.org/10.1006/eesa.2000.2007

Fountain, M. T. \& Hopkin, S. P. (2005): Folsomia candida (Collembola): a 'standard' soil arthropod. - Annual Review of Entomology 50: 201-222. https://doi.org/10.1146/annurev. ento.50.071803.130331

Fox, C. W., Thakar, M. S. \& Mousseau, T. A. (1997): Egg size plasticity in seed beetle: an adaptive maternal effect. - The American Naturalist 149(1): 149-163. https://doi. org/10.1086/285983

Gardiner, S. A., Boddu, J., Berthiller, E., Hametner, C., Stupar, R. M., Adam, G. \& MueHLbAUER, G. J. (2010): Transcriptome analysis of the barley-deoxynivalenol interaction: evidence for a role of glutathione in deoxynivalenol detoxification. - Molecular Plant-Microbe Interactions 23(7): 962-976. https://doi.org/10.1094/MPMI-23-7-0962

Goncharov, A. A., Glebova, A. A. \& Tiunov, A. V. (2020): Trophic interactions between Fusarium species and soil fauna: a meta-analysis of experimental studies. - Applied Soil Ecology 145: 103302. https://doi.org/10.1016/j.apsoil.2019.06.005

Gото, Н. Е. (1960): Simple techniques for the rearing of Collembola and a note on the use of a fungistatic substance in the cultures. https://doi.org/10.1016/j.apsoil.2019.06.005 Entomologists' Monthly Magazine 96: 138-140.

Hopкin, S. P. (1997): Biology of the springtails (Insecta: Collembola). - Oxford University Press, Oxford, 330 pp. https://doi.org/10.1016/j.apsoil.2019.06.005

Horn, B. W. (2003): Ecology and population biology of aflatoxigenic fungi in soil. - Journal of Toxicology - Toxin Reviews 22(2-3): 351-379. https://doi.org/10.1081/TXR-120024098

InNocenti, G. \& SABAtini, M. A. (2018): Collembola and plant pathogenic, antagonistic and arbuscular mycorrhizal fungi: A review. - Bulletin of Insectology 71(1): 71-76.

Janssens, T. K. S., Staaden, S., Scheu, S., Mariën, J., Ylstra, B. \& Roelofs, D. (2010): Transcriptional responses of Folsomia candida upon exposure to Aspergillus nidulans secondary metabolites in single and mixed diets. - Pedobiologia 54(1): 45-52. https:// doi.org/10.1016/j.pedobi.2010.09.002

Ji, C., FAN, Y. \& ZhaO, L. (2016): Review on biological degradation of mycotoxins. - Animal Nutrition 2(3): 127-133. https://doi.org/10.1016/j.aninu.2016.07.003

Kövesi, B., Pelyhe, C., Zándoki, E., Mézes, M. \& Balogh, K. (2019): Effect of short-term sterigmatocystin exposure on lipid peroxidation and glutathione redox system and expression of glutathione redox system regulatory genes in common carp liver. Toxicon 161(September 2018): 50-56. https://doi.org/10.1016/j.toxicon.2019.03.001

Krogh, P. H. (2009): Toxicity testing with the collembolans Folsomia fimetaria and Folsomia candida and the results of a ringtest. - Miljøundersøgelser, 1-66 pp.

Larsen, J., Johansen, A., Larsen, S. E., Heckmann, L. H., Jakobsen, I. \& Krogh, P. H. (2008): Population performance of collembolans feeding on soil fungi from different ecological niches. - Soil Biology and Biochemistry 40(2): 360-369. https://doi.org/10.1016/j. soilbio.2007.08.016

Li, Y., Wang, Z., Beier, R. C., Shen, J., Smet, D. De, Saeger, S. De \& Zhang, S. (2011): T-2 toxin, a trichothecene mycotoxin: review of toxicity, metabolism, and analytical methods. - Journal of Agricultural and Food Chemistry 59(8): 3441-3453. https://doi. org/10.1021/jf200767q

Logrieco, A., Mule, G., Moretti, A. \& Bottalico, A. (2002): Toxigenic Fusarium species and mycotoxins associated with maize ear rot in Europe. - European Journal of Plant Pathology 108: 597-609. https://doi.org/10.1023/A:1020679029993 
Lowry, O. H., Rosebrough, N. J., Farr, A. L. \& RandallL, R. J. (1951): Protein measurment with the Folin phenol reagent. - Analytical Biochemistry 217(2): 220-230. https://doi. org/10.1016/0304-3894(92)87011-4

LushснAк, V. I. (2011): Adaptive response to oxidative stress: bacteria, fungi, plants and animals. - Comparative Biochemistry and Physiology - C Toxicology and Pharmacology 153(2): 175-190. https://doi.org/10.1016/j.cbpc.2010.10.004

LuSHснAк, V. I. (2012): Glutathione homeostasis and functions: potential targets for medical interventions. - Journal of Amino Acids 2012: 1-26. https://doi.org/10.1155/2012/736837

Maria, V. L., Ribeiro, M. J. \& Amorim, M. J. B. (2014): Oxidative stress biomarkers and metallothionein in Folsomia candida - responses to $\mathrm{Cu}$ and $\mathrm{Cd}$. - Environmental Research 133: 164-169. https://doi.org/10.1016/j.envres.2014.05.027

Matкovics, B., Szabó, L. \& Sz. VARGA, I. (1988): Determination of lipid peroxidation and glutathione metabolism enzymes in biological samples. - Journal of Laboratory Diagnostics 15: 248-250.

Mousseau, T. A. \& Fox, C. W. (1998): The adaptive significance of maternal effects. - Trends in Ecology \& Evolution 13(10): 403-407. https://doi.org/10.1016/S0169-5347(98)01472-4

Nagy, C. M., Fejer, S. N., Berek, L., Molnar, J. \& Viskolcz, B. (2005): Hydrogen bondings in deoxynivalenol (DON) conformations- a density functional study. - Journal of Molecular Structure: THEOCHEM 726(1-3): 55-59. https://doi.org/10.1016/j.theochem.2005.02.079

Ommen Kloeke, A. E. E. van, Gestel, C. A. M. van, Styrishave, B., Hansen, M., Ellers, J. \& Roelofs, D. (2012): Molecular and life-history effects of a natural toxin on herbivorous and non-target soil arthropods. - Ecotoxicology 21(4): 1084-1093. https://doi. org/10.1007/s10646-012-0861-z

Pinheiro, J., Bates, D., DebRoy, S., Sarkar, D. \& R Core Team (2013): nlme: Linear and non-linear mixed effect models. $\mathrm{R}$ package version 3.1-119.

Placer, Z. A., Cushman, L. L. \& Johnson, B. C. (1966): Estimation of product of lipid peroxidation (malonyl dialdehyde) in biochemical systems. - Analytical Biochemistry 16(2): 359-364. https://doi.org/10.1016/0003-2697(66)90167-9

Pussemier, L., Piérard, J.-Y., Anselme, M., Tangni, E. K., Motte, J.-C. \& Larondelle, Y. (2006): Development and application of analytical methods for the determination of mycotoxins in organic and conventional wheat. - Food Additives and Contaminants 23(11): 1208-1218. https://doi.org/10.1080/02652030600699312

R Core Team (2020): R: A language and environment for statistical computing. - Vienna, Austria, https://www.R-project.org/

Rahman, I., Kode, A. \& Biswas, S. K. (2007): Assay for quantitative determination of glutathione and glutathione disulfide levels using enzymatic recycling method. - Nature Protocols 1(6): 3159-3165. https://doi.org/10.1038/nprot.2006.378

Rohlfs, M., Albert, M., Keller, N. P. \& Kempken, F. (2007): Secondary chemicals protect mould from fungivory. - Biology Letters 3(5): 523-525. https://doi.org/10.1098/ rsbl.2007.0338

SAtTerly, J. (1960): Formulae for volumes, surface areas and radii of gyration of spheres, ellipsoids and spheroids. - The Mathematical Gazette 44(347): 15-19. https://doi. org/10.2307/3608515

Schneider, C. A., RAsband, W. S. \& Eliceiri, K. W. (2012): NIH Image to ImageJ: 25 years of image analysis. - Nature Methods 9: 671-675. https://doi.org/10.1038/nmeth.2089

Sies, H. (1999): Glutathione and its role in cellular functions. - Free Radical Biology and Medicine 27(9-10): 916-921. https://doi.org/10.1016/S0891-5849(99)00177-X 
Smit, C. E., Stam, E. M., BaAs, N., Hollander, R. \& Gestel, C. A. M. van (2004): Effects of dietary zinc exposure on the life history of the parthenogenetic springtail Folsomia candida (Collembola: Isotomidae). - Environmental Toxicology and Chemistry 23(7): 1719-1724. https://doi.org/10.1897/03-287

Speijers, G. J. A. \& Speijers, M. H. M. (2004): Combined toxic effects of mycotoxins. - Toxicology Letters 153(1): 91-98. https://doi.org/10.1016/j.toxlet.2004.04.046

Staaden, S., Milcu, A., Rohlfs, M. \& Scheu, S. (2010): Fungal toxins affect the fitness and stable isotope fractionation of Collembola. - Soil Biology and Biochemistry 42(10): 1766-1773. https://doi.org/10.1016/j.soilbio.2010.06.014

Stötefeld, L., Scheu, S. \& Rohlfs, M. (2012): Fungal chemical defence alters density-dependent foraging behaviour and success in a fungivorous soil arthropod. - Ecological Entomology 37(5): 323-329. https://doi.org/10.1111/j.1365-2311.2012.01373.x

Szabó-Fodor, J., Kachlek, M., Cseh, S., Somoskói, B., Szabó, A., Blochné Bodnár, Z., Tornyos, G., Mézes, M., Balogh, K., Glávits, R., Hafner, D. \& Kovács, M. (2015): Individual and combined effects of subchronic exposure of three fusarium toxins (fumonisin B, deoxynivalenol and zearalenone) in rabbit bucks. - Journal of Clinical Toxicology 5(4): 264. https://doi.org/10.1016/j.jvoice.2012.02.001

Szabó, B., Kocsis, R. \& Mézes, M. (2019): Reproduction inhibiting effects of deoxynivalenol or T-2 toxin contaminated maize on Folsomia candida (Collembola). - Acta Zoologica Academiae Scientiarum Hungaricae 65(4): 323-334. https://doi.org/10.17109/ AZH.65.4.323.2019

Szabó, B., Seres, A. \& Bakonyi, G. (2018): Folsomia candida (Collembola) locomotor activity pattern is changed by a neurotoxicant pesticide. - Acta Zoologica Academiae Scientiarum Hungaricae 64(4): 355-368. https://doi.org/10.17109/AZH.64.4.355.2018

Szabó, B., Seres, A. \& Bakonyi, G. (2017): Long-term consumption and food replacement of near-isogenic by Bt-maize alter life-history traits of Folsomia candida Willem 1902 (Collembola). - Applied Ecology and Environmental Research 15(4): 1275-1286. https:// doi.org/10.15666/aeer/1504_12751286

Taguchi, K., Мотонаshi, H. \& Yамамото, M. (2011): Molecular mechanisms of the Keap1Nrf2 pathway in stress response and cancer evolution. - Genes to Cells 16(2): 123-140. https://doi.org/10.1111/j.1365-2443.2010.01473.x

Traverso, N., Menini, S., Maineri, E. P., Patriarca, S., Odetti, P., Cottalasso, D., MariNARI, U. M. \& Pronzato, M. A. (2004): Malondialdehyde, a lipoperoxidation-derived damage to proteins. - Journal of Gerontology 59(9): 890-895. https://doi.org/10.1093/ gerona/59.9.B890

Trebstein, A., Seefelder, W., Lauber, U. \& Humpf, H.-U. (2008): Determination of T-2 and HT-2 toxins in cereals including oats after immunoaffinity clean-up by liquid chromatography and fluorescence detection. - Journal of Agriculture and Food Chemistry 56: 4968-4975. https://doi.org/10.1021/jf800316m

Tully, T. \& Ferrière, R. (2008): Reproductive flexibility: genetic variation, genetic costs and long-term evolution in a collembola. - PloS ONE 3(9): e3207. https://doi.org/10.1371/ journal.pone.0003207

Vandegehuchte, M. B., Vandenbrouck, T., Coninck, D. de, Coen, W. M. de \& Janssen, C. R. (2010): Gene transcription and higher-level effects of multigenerational Zn exposure in Daphnia magna. - Chemosphere 80(9): 1014-1020. https://doi.org/10.1016/j. chemosphere.2010.05.032

Vega, F. E. \& Mercadier, G. (1998): Insects, coffee and ochratoxin A. - The Florida Entomologist 81(4): 543-544. https://doi.org/10.2307/3495953 
WANG, G., WANG, Y., Ji, F., Xu, L., YU, M., ShI, J. \& XU, J. (2019): Biodegradation of deoxynivalenol and its derivatives by Devosia insulae A16. - Food Chemistry 276(September 2018): 436-442. https://doi.org/10.1016/j.foodchem.2018.10.011

WANG, Y., WANG, B., LiU, M., JiANG, K., WANG, M. \& WANG, L. (2019): Comparative transcriptome analysis reveals the different roles between hepatopancreas and intestine of Litopenaeus vannamei in immune response to aflatoxin B1 (AFB1) challenge. Comparative Biochemistry and Physiology, Part C: Toxicology and Pharmacology 222: 1-10. https://doi.org/10.1016/j.cbpc.2019.04.006

WANG, Y., WANG, G., DAI, Y., WANG, Y., LeE, Y. W., SHI, J. \& XU, J. (2020): Biodegradation of deoxynivalenol by a novel microbial consortium. - Frontiers in Microbiology 10: 2964. https://doi.org/10.3389/fmicb.2019.02964

Wolfarth, F., Schrader, S., Oldenburg, E. \& Weinert, J. (2013): Nematode-collembolaninteraction promotes the degradation of Fusarium biomass and deoxynivalenol according to soil texture. - Soil Biology and Biochemistry 57: 903-910. https://doi. org/10.1016/j.soilbio.2012.11.001

Wu, Q., Wang, X., Nepovimova, E., Wang, Y., Yang, H., Li, L., Zhang, X. \& Kuca, K. (2017): Antioxidant agents against trichothecenes: new hints for oxidative stress treatment. Oncotarget 8(66): 110708-110726. https://doi.org/10.18632/oncotarget.22800

Zhai, Y., Zhong, L., GaO, H., Lu, Z., Bie, X., Zhao, H., Zhang, C. \& Lu, F. (2019): Detoxification of deoxynivalenol by a mixed culture of soil bacteria with 3-epi-deoxynivalenol as the main intermediate. - Frontiers in Microbiology 10: 1-12. https://doi.org/10.3389/ fmicb.2019.02172

Received July 30, 2020, accepted September 26, 2020, published November 13, 2020 